\title{
Current invasive and non-invasive biomarkers in canine mammary tumors
}

\author{
Aslıhan BAYKAL ${ }^{1, *}$ Özge TURNA ${ }^{1}$
}

\section{Review Article}

Volume: 5, Issue: 1

April 2021

Pages: 39-56

\section{Article History}

Received: 08.03.2021

Accepted: 07.04.2021

Available online:

08.04.2021
1. Istanbul University-Cerrahpaşa, Veterinary Medicine, Department of Obstetrics and Gynaecology, 34320, Istanbul, Turkey. Baykal A: ORCID: 0000-0002-2107-1874, Turna Ö: ORCID: 0000-0002-7638-0519.

\begin{abstract}
In bitches, the incidence of mammary tumors is determined at $\% 50$ of all neoplasms. Most of the cases are malignant and tend to metastasize. Because of this, early diagnosis has an important value. Due to the molecular and clinical similarities of canine mammary tumors to human breast cancers, human breast cancer markers are also detectable in cases of canine mammary tumors. Generally, biomarkers provide information about criteria such as clinical diagnosis, early diagnosis, prognosis, and determination of the treatment protocol. When choosing the appropriate biomarker, it should be taken into account that it is easy to apply, has a positive correlation with tumor specificity and malignancy, and whether gives precise information about prognosis. Due to the heterogeneous nature of canine mammary tumors, an ideal biomarker has not determined yet. However, new studies have revealed the existence of many biomarkers. In this review it is given to qualified and current biomarkers can be used in dogs, including invasive and non-invasive mammary tumor biomarkers.
\end{abstract}

Keywords: biomarkers, dogs, mammary neoplasms

DOI: https://doi.org/10.30704/http-www-jivs-net.892668

To cite this article: Baykal, A., Turna Ö. (2021). Current invasive and non-invasive biomarkers in canine mammary tumors. Journal of Istanbul Veterinary Sciences, 5(1), 39-56. Abbreviated Title: J. İstanbul vet. sci.

\section{Introduction}

Mammary tumors are among the frequent neoplasms in bitches (Lana et al., 2007). Malign tumors constitute approximately $40-50 \%$ of the cases (Sorenmo et al., 2003). Besides, $50 \%$ of the malign masses tend to metastasis (Sleeckx et al., 2011). The studies conducted report that the most frequent mammary tumor types in dogs are mixed tumors (67\%), adenoma and adenocarcinoma (32\%) (Casalli et al., 2012). In its etiology, particularly steroid hormones play a role as well as the genetic, breed predisposition, nutrition, and environmental factors (Sorenmo et al., 2003; Chang et al., 2009; Beauvais et al., 2012). Although mammary tumors are detected in very old animals, it inclines to occur between the ages of 8-10 years (Sorenmo et al., 2003). Another reason for the increased incidence of mammary

*Corresponding Author: Aslıhan Baykal E-mail: aslihan.baykal@istanbul.edu.tr tumors is the time of neutering. While the risk for an animal to develop mammary tumor associated to prepubertal neutering is $0.5 \%$, the risk increases in the subsequent cycles (Sorenmo et al., 2003). Besides, frequent phantom pregnancy/ false pregnancy or administration of exogenous progesterone also increase the risk of mammary tumors (Benavente et al., 2016).

Following the removal of the tumor by surgical incision, prognostic assessment is based on clinical grading, size of the tumor, spread to lymph nodes, existence of metastasis, and lymphatic and vascular invasion. Histopathologic examination is conducted according to the criteria determined by World Health Organization (Perez Alenza et al., 2000; Sorenmo et al., 2003; Ferreira et al., 2009; Santos et al., 2013; Tavasoly et al.,

Journal home page: www.jivs.net http://dergipark.gov.tr/http-www-jivs-net 
2013). Typically, chemotherapy or radiotherapy is preferred for malignant masses based on the result of histopathology. However, the failure to determine the efficiency of the treatment protocols produces various restrictions such as toxic effect and high costs. Similar to humans, it is reported that the efficiency of the treatment in dogs may be limited due to the micrometastasis which have already been occurred at the treatment stage (Rogers, 1993). This emphasizes the importance of early diagnosis. Ki-67, CEA (Carcinoembryonic Antigen), VEGF (Vascular Endothelial Growth Factor) may be given as examples to diagnostic biomarkers. Although there is no sufficient information in the literature regarding the accuracy of the biomarkers used in veterinary medicine, the studies on this matter have increased recently. Human breast neoplasm cases resemble the canine mammary tumors in molecular and clinical aspects. As they have similarities in immunohistochemical properties, it is concluded that the same biomarkers may be used (Pena et al., 2014). Yet, the heterogeneous morphology of canine mammary tumor poses a challenge in the selection of the most suitable biomarker (Gama et al., 2008). The purpose of this review is to include the current invasive and non-invasive biomarkers proven to be used in canine mammary tumors.

\section{A. Invasive Biomarkers}

\section{1. miRNA}

miRNA, known as short non-coding RNA, is available in eucaryotes such as animals and plants. It has an important role in the regulation of gene expression at post-transcription level. Besides, miRNAs participate in the regulation of cellular growth, proliferation, differentiation, and apoptosis (O'day et al., 2010). Studies indicate that detecting the miRNA in circulation might be an important diagnostic tool in tumor cases. In addition to diagnosis and prognosis, miRNAs are also used in the selection of the efficient chemotherapy and considered as an effective biomarker for treatment. Irrespective of the histological type, miRNA profile of canine mammary tumors is expressed at different levels based on the malignity, type, and metastasis factory of the tumor (Bulkowska et al., 2017).
While some miRNAs are upregulated in cancer cases, others show down-regulation; and this indicates that miRNAs may move as oncogene or tumor suppressor genes (lorio et al., 2005). They are used both as tissue and serum biomarkers (Kaszak et al., 2018). Despite the numerous studies on miRNA in human medicine, the number of studies in veterinary medicine is limited. Bulkowska et al. (2017) reported that 9 out of 10 miRNA expressed in humans were similarly expressed in canine mammary tumors. According to researchers, miR-15a and miR-16 show down-regulation in ductal carcinoma samples, and miR-181b, miR-21, miR29b and miRlet-7f show up-regulation in tubular papillary carcinomas. Similar studies prove the existence of miRNA's mentioned related to human breast neoplasms in canine mammary tumors (Boggs et al., 2008; Chou et al., 2013; Lutful Kabir et al., 2015; Sahabi et al., 2018).

\section{Ki-67}

One of the well-established biomarkers in canine mammary tumors and an important one in the assessment of proliferation and apoptosis is $\mathrm{Ki}-67$ (Zuccari et al., 2004). In addition to these, Ki-67 demonstrated positive correlation with parameters such as metastasis and survival (Pena et al., 1998). The increase in Ki-67 expression is typically associated with the size of the tumor, presence of ulcers, poor clinical picture such as inflammation, invasion towards surrounding tissues and involvement of lymph nodes (Lohr et al., 1997; Nowak et al., 2015; Rodrigues et al., 2016). Ki-67 may only be detected during the cell cycle on chromosomes, and it may not be detected in cells outside of the division phase (G0) (Scholzen and Gerdes, 2000; Endl et al., 2001). The availability of Ki-67 expression during the cell cycle and the non-availability of this expression at resting phase enable it to be the cell proliferation biomarker considered as an indication of neoplastic changes (Neumann et al., 2016). Another study reviewed the determination of Ki-67 antigen in canine mammary tumors using Diff-Quick method (Choi et al., 2009). It was concluded that Ki-67 antigen might be detected using Diff-Quick method when histopathology is not possible. Obtaining significant results through 
cytological methods allowed $\mathrm{Ki}-67$ to be one of the biomarkers that may be used for early diagnosis.

\section{PCNA (Proliferating Cell Nuclear Antigen)}

Besides being a proliferation biomarker, the concentration of PCNA fluctuates throughout the cell cycle, and a significant increase occurs in $S$ phase which is one of the interphase stages (Bravo and Celis, 1980; Celis and Celis, 1985). PCNA plays a role in the nucleic acid metabolism, and it is responsible for essential DNA replication, cell cycle control, and RNA transcription (Juríková et al., 2016). In dogs with mammary tumors, PCNA expression was reported to be positively correlated with tumor size, ulceration, lymph node metastasis and degree of malignity, and that, accordingly, higher expressions might be associated with low survival and poor prognosis (Carvalho et al., 2016). However, PCNA expression may also be stimulated by cytokines. Therefore, it is not suitable to be used as the sole specific biomarker for cancer cases. Thus, it should be used combined with another biomarker (Kazsak et al., 2018).

\section{Protein p53}

p53 gene participates in DNA repair, regulation of cell cycle and apoptosis (Lee et al., 2004). In addition to these, it has tumor suppressing property, but it gains oncogenic property by accumulating in tumor tissue due to gene mutation during tumor development (Gasco et al., 2002). The studies conducted indicate that increased expressions are associated with the degree of malignity and low survival. (Lee et al., 2004; Łopuszyński et al., 2010).

As detected in human breast neoplasm cases, it was concluded that the existence of necrosis is associated with the increase in p53 expression (Kato et al., 2002; Dolka et al., 2016). A study reported that $\mathrm{p} 53$ positive mammary tumors are more frequent in large dog breeds, particularly in Boxers; this gene mutation may be genetic; and therefore, genetic susceptibility should be considered during assessments (Veldhoen et al., 1999). As in human medicine, increased expressions of p53 gene are important in veterinary medicine in terms of prognosis, and therefore, the use of the mentioned biomarker should be supported by future studies.

\section{E-cadherin}

E-cadherin is a member of cadherins known to have an important role in the regulation of cellcell adhesion in epithelial tissues (Takeichi et al., 1991). E-cadherin is expressed on basolateral surfaces of epithelial cells and at the contact points of cells (Boller et al., 1985). In addition to tissue morphogenesis and differentiation, it participates in processes such as cell shape, proliferation. E-cadherin is located in mammary gland which is one of the epithelial tissues, and it ensures functional and structural integrity of the gland (Andrews et al., 2012). Low expressions occur in transition from epithelial origin to mesenchymal origin, and this reduction in expression is associated with the progress of the case towards malignity (Chan et al., 2015).

Transition from epithelial to mesenchymal origin causes the invasion and spread of tumor cells and occurs when the epithelial cells gain mesenchymal properties (Baranwal et al., 2009; Chan et al., 2015).

Immunohistochemical analysis exhibited that E-cadherin membrane expression reduces in canine mammary carcinoma (Asproni et al., 2015). This result was associated with aggressive clinical features observed in canine mammary carcinomas such as high mitotic index, large tumor size, infiltration, invasion, and lymph node metastasis (Brunetti et al., 2003; Matos et al., 2006; Gama et al., 2008). Besides, it is agreed that E-cadherins have an effect on tumor suppression. In tumors with partial or total loss of E-cadherin expression, higher infiltration and lymph node involvement were observed (Heimann et al., 2000). Reduced E-cadherin expression in canine mammary tumors were found to be associated with poor prognosis (Matos et al., 2006). It was also presented that low or negative E-cadherin expression in canine mammary tumors is a marker associated with aggressive properties exhibited by the tumor (Varallo et al., 2019).

\section{CEA (Carcinoembryonic antigen)}

Carcinoembryonic antigen (CEA) is produced by the cells located in gastrointestinal mucosa (Almeida et al., 2007). It participates in 
intercellular adhesion (von Kleist et al., 1995). Increased expression occurs in breast, lung, and rectum adenocarcinoma cases (Souza et al., 2002). In human breast neoplasms, it is used in combination with CA 15-3 biomarker (Ledecky et al., 2013). Besides, European Group on Tumor Markers recommends using CEA and CA15-3 levels together in the early detection of disease progression and in the assessment of the treatment follow-up in breast cancer (Molina et al., 2005). On the other hand, regarding the use of CA 15-3 and CA together, American Society of Clinical Oncology suggests that the use of these biomarkers in monitoring, staging and routine surveillance of the disease after primary treatment would not lead to accurate data (Harris et al., 2007; Cardoso et al., 2008). While CEA may be detected in canine mammary tumor tissue, it is found at higher levels in tumor tissues compared to healthy tissues (Campos et al., 2012; Ledecky et al., 2013). There is no sufficient literature in veterinary medicine on this matter, and new research should be conducted to determine its usability in disease follow-up and other roles in the assessment of disease.

\section{CA 15-3 (Carbohydrate antigen)}

Carbohydrate antigen (CA 15-3) is a product of mucin 1 (MUC1) gene, and it is used as a biomarker which is expressed in high levels in adenocarcinomas and which may subsequently be detected in circulation (Perey et al., 1992; Hayes et al., 2012). Malignant changes that occur in the tissue and the changes in the structure of the relevant cells lead CA 15-3 to increase in the circulation, and from this aspect, CA 15-3 is accepted as an essential biomarker which may be used in detecting mammary gland carcinoma (Kausitz et al., 2003). During the transformation to malignity, MUC1 acts like an anti-adhesive molecule and causes the malign cells separate from each other; this increases the invasion and metastatic potential in tumor cells (Kaszak et al., 2018). Manuali et al. (2012) reviewed the correlation between the expression of CA 15-3 in cell line and tissue and the histological staging of tumor in canine mammary tumors. At the end of the trial, it was presented that CA 15-3 was expressed at higher levels at grade I compared to grade II and grade III carcinomas. This finding suggests that CA $15-3$ is associated with parameters such as poor clinical picture, poor prognosis, tumor size, ulceration, and inflammation.

\section{VEGF}

Vascular endothelial growth factor (VEGF) is a protein that stimulates the migration and proliferation of vascular endothelial cells which have an important role in angiogenesis (Restucci et al., 2002). VEGF is produced by neoplastic cells, macrophages, and plasma cells, and it also stimulates the growth of neoplastic cells (Lui et al., 1995). It is typically used for the assessment of angiogenesis in human medicine. VEGF synthesis in many malignant tumor cases is associated with metastasis (Takahashi et al., 1995). VEGF expression is highest in tumors with significant necrosis, and this is known to occur associated with hypoxia in necrotic areas (Shweiki et al., 1992). This is because hypoxia has an effect of increasing the transcription of VEGF coding gene (Ikeda et al., 1995). The studies on canine mammary tumor present that high VEGF expressions are associated with poor prognosis and low survival (Queiroga et al., 2011). Similar to human medicine, its combined or individual use is indicated to be important for early diagnosis also in veterinary medicine (Lawicki et al., 2016; Zajkowska et al., 2016).

\section{EGFR (HER-1)}

Epidermal growth factor receptor (EGFR) is a transmembrane protein and participates in the regulation of morphogenesis, proliferation, migration, and adhesion in cells (Yarden and Sliwkowski, 2001). It is proven that EGFR expression occurs in aggressive canine mammary tumors (Gama et al., 2009). High EGFR expressions are also associated with stimulated angiogenesis and poor prognosis (Carvalho et al., 2013; Queiroga et al., 2017). Guimaraes et al. (2014) studied whether there was a relation between Cox- 2 and EGFR in canine mammary tumors. As both parameters studied had positive correlation with each other, they concluded that EGFR and Cox-2 inhibitors may be a treatment option in canine mammary tumors. The studies conducted indicate that EGFR may be used in 
clinical picture assessment and the inhibitors may be used in treatment protocol.

\section{HER-2}

Human epidermal growth factor receptor (HER-2) is one of the important biomarkers in mammary tumor cases. HER-2 regulates the events such as tumor growth, survival, and differentiation (Kazsak et al., 2018). Studies suggest that increased expressions of HER-2 protein in canine mammary tumors indicate poor prognosis (Dutra et al., 2004). On the other hand, in some studies, it was determined that the patient had longer survival time in malignant mammary tumors with high HER-2 expression (Lüftner et al., 2003). Supporting this finding, a study conducted by Hsu et al. (2009) analyzed the survival time with HER2 expression. When the survival time were reviewed at the end of one year in trial, it was concluded that dogs with HER-2 positive had longer survival time. Accordingly, it was identified that HER-2 is not suitable to use directly in determining development and malignity. However, the area of use of this biomarker should be supported with new studies as there are opposite findings.

\section{PR/ER}

Estrogens bind to estrogen receptors (ER) in healthy canine mammary gland. When malignant masses were compared with benign masses or normal tissue in terms of ER expression, it was observed that the expression was low in malignant tumors (Canadas-Sousa et al., 2019). In addition to this, reduced ER expression is associated with large size of the mass and lymph node involvement, and therefore, ER is accepted as a marker with prognostic importance (Nieto et al., 2000; Las Mulas et al., 2005). Progesterone has severe effects on the growth and differentiation of normal mammary gland and malignant mammary epithelial growth (Queiroga et al., 2015). In a study, the expression levels of steroid hormones in serum and tissue were analyzed and at the end, an increased expression in malignant tumors was detected (Queiroga et al., 2015). There are studies that support the opposite of these findings. In a study where the progesterone receptor (PR) expression was reviewed a gradual reduction in $P R$ expression was observed in hyperplastic, benign, and malign masses, respectively (Millanta et al., 2005).

Unlike the chemotherapy protocol administered to human breast tumor cases, the use of hormones in canine mammary tumors is not widespread due to the side effects. There is a single study which reviewed the potential therapeutic effect of tamoxifen and determined the safe dosage range (Tavares et al., 2010). However, the side effects of tamoxifen used in dogs with estrogenic effect such as pyometra should be taken into account (Morris et al., 1993).

\section{Oxytocin}

Oxytocin is essentially synthesized in hypothalamus and secreted by neurohypophysis and participates in different biological functions. (Zingg and Laporte, 2003). In the mammary gland, oxytocin primarily ensures lactation with the contraction of the myoepithelial cells (Geddes, 2007). Recently, the effect of oxytocin hormone on human breast neoplasm has been revealed (Cassoni et al., 2004). But the role of oxytocin receptors in dogs in the formation of tumors in mammary tissue has not yet been clarified. In a study conducted in 2012, the existence of oxytocin receptor expression on canine mammary tumor cell line was determined (Bergman, 2012), and the subsequent study revealed that oxytocin might have antiproliferative effect on cell line (Benavente et al., 2016). In another study by Benavente et al. (2019), the existence of oxytocin receptor expression was detected in all samples. When classified based on the histological grades, the oxytocin receptor expression among malign tumors was found significantly high in Grade III compared to Grade I and Grade II. In fibroadenoma, adenoma and benign mixed tumor group, it was shown that the expression in samples with fibroadenoma was higher, and there was not a significant difference between solid carcinoma, carcinosarcoma and tubulopapillar carcinoma samples. As a result, benign tumors have higher oxytocin receptor expression than malign tumors. When ER and ER malign mammary tumors were compared, the oxytocin receptor expression in ER tumors was found significantly higher, and no relation was detection between ER tumors and oxytocin 
receptor expression. Finally, it was suggested that oxytocin receptor expression is not associated with tumor size, clinic phase or lymph node involvement. Based on this study, it may be proposed that oxytocin receptor expression may be used as cellular differentiation biomarker. The change in oxytocin receptor expression based on malignity in canine mammary tumors should be supported with new studies.

\section{Heat-scock proteins}

\section{1. $\alpha \mathrm{B}$-crystallin}

Heat-shock proteins is a group of proteins that increase with the exposure of cells to high temperature. Other stress factors except for high temperature may also cause an increase in these proteins. It participates in correct folding of the proteins or ensuring the detachment of wrong folded proteins from each other. The substances that assist the correct folding of proteins in the cell are called 'molecular chaperones' (Ellis et al., 1991; Deocaris et al., 2006; ChmielewskaKrzesinska et al., 2019). Many tumor cells produce high levels of chaperones. Heat-shock proteins released out of the cell participate in the spread of tumor cells to surrounding or farther tissues. belonging to small heat-shock proteins family, ATP inhibits the wrong folding and accumulation of proteins as an independent molecular chaperone (Bakthisaran et al., 2015). Besides, it supports the oncogenic transformation and participates in carcinogenesis at the transition from epithelial origin to mesenchymal origin in form of anoikis resistance, angiogenesis, and organ specific colonization (Malin et al., 2016). In a study by Chmielewska-Krzesinska et al. (2019), the usability of gene expression as a circulating tumor cell biomarker was reviewed. Circulating tumor cells are those which may be detected in blood in epithelial tumors produced from the primary focus or its metastasis (Plaks et al., 2013). Therefore, the use of circulating tumor cells as biomarkers may be important in determining the cells likely to form metastasis. So, the 'circulating tumor cells (CTCs)' may be recommended as biomarker for canine mammary tumors (da Costa et al., 2011). In the majority of the cases, gene expression was detected higher in tumor tissue than healthy tissue. Besides, increased expression of is associated with aggressive tumor characteristics and poor clinical picture (Goplen et al., 2010; Malin et al., 2014; Shi et al., 2016). In another study, it is indicated that $C R Y A B$ and CK17 expressions occurred $90 \%$ together in canine mammary adenoma and carcinoma, and therefore, these two genes might be referred to jointly (Chmielewska-Krzesinska et al., 2019). According to this, while CRY $A B$ and CK17 increased by $70 \%$ in adenoma group, this increase was found to be $50 \%$ in carcinoma group. It was concluded that might be considered as a circulating tumor cells biomarker, but it might not be used as a universal biomarker. Due to the difference between the data and the lack of further literature regarding the given biomarker, there should be more studies related to the use of gene expression as a biomarker in veterinary medicine.

\subsection{HSP9OB1}

Hsp90 is a member of heat-shock proteins family and plays an important role in mammary tumors. Hsp90B1 gene is expressed at high levels on many cancer cell lines and associated with aggressive growth and invasion (Lee et al., 2014). It is also associated with increased expression, distant metastasis, and decreased survival time on mammary cancer cell line (Cawthorn et al., 2012). Grp94 (Glucose regulated protein) is the endoplasmic reticulum paralogue coded by Hsp90B1 gene (Sunil Kumar et al., 2017). Carcinogenesis causes nutrition and hypoxic stress in cells and damages the protein mechanism. The wrong folded or unfolded proteins due to the damaged protein mechanism accumulate in endoplasmic reticulum lumen. Eventually, Grp94 expression increases to protect cell homeostasis. Besides, Grp94 participates in the living, proliferation, and invasion of cancer tumors (Scheuner et al., 2001; Nami et al., 2016). In a study, Hsp90B1 mRNA expression was compared in healthy and tumorous mammary tissues (Sunil Kumar et al., 2017). In this context, Hsp90B1 mRNA expression in tumorous tissues in form of carcinosarcoma, complex carcinoma, fibrosarcoma and simple carcinoma was higher than healthy tissues. In tumorous tissues, only simple carcinoma occurred significantly lower 
compared to other tumor subtypes. Data obtained suggest that Grp94 is a promising biomarker in the assessment of prognosis although there are no sufficient sources regarding the correlation in serum concentration.

\section{Interleukins}

\subsection{Interleukin-6 and interleukin-10}

As the tumor growth and progression is controlled by the immune system, the importance of availability of cytokines in the occurrence of these events is proven in various studies (Lin and Karin, 2007; Fernandes et al., 2015). While certain cytokines participate in the mechanisms causing the growth and progression of the tumor, some involve in the mechanisms inhibiting the tumor growth (Nicolini et al., 2006; Newman and Gonzalez-Perez, et al. 2014). Interleukin-6 (IL-6) is a pro-inflammatory cytokine, and tumor cells play a role in its production (Ben-Baruch, 2003; Kim et al., 2010). Besides, IL-6 supports tumor growth and progression as it has numerous effects on tumor cell proliferation, patient's survival time and formation of metastasis (Nicolini et al., 2006). Studies on canine mammary tumor associate high levels of IL-6 in serum with poor prognosis (Estrela-Lima et al., 2016; Martins et al., 2016). Interleukin 10 (IL-10) is an anti-inflammatory cytokine and inhibits the pro-inflammatory cytokine production. It is also considered that IL10 has an anti-tumor activity and supports tumor growth (Changkija et al., 2012). Merendione et al. (1996) reviewed increased IL-10 concentration and concluded that this increase is in correlation with advanced clinical findings. Estrela-Lima et al. (2016) addressed the change of IL-10 concentration in dogs with metastatic mammary tumor. As a result, they determined that IL-10 concentration was higher in the existence of metastasis compared to non-metastatic cases. In another study supporting the mentioned study, it was concluded that IL-10 concentrations were higher in inflammatory adenocarcinoma cases compared to non-inflammatory adenocarcinoma cases (De Andres et al., 2013). In light of these information, a study on healthy plasmas and plasmas wit mammary tumors in dogs investigated the usability of IL-6 and IL-10 as a biomarker in canine mammary tumors (Szczubial et al., 2018). It was detected that plasma IL-6 concentration in dogs with mammary tumor was higher compared to healthy dogs, and it was higher in Grade 3 tumors then Grade 1 tumors. IL10 was detected at significantly higher levels only in malign tumors. The higher concentrations of IL6 in Grade 3 tumors indicate that the mentioned cytokine has a positive correlation with the increase in the malignity grade of the tumor, and therefore, it may be used as a potential diagnostic and prognostic biomarker. The increase in IL-10 concentration suggests that it may assist in the assessment of the malign form.

\section{2. İnterleukin-35}

Interleukin-35 (IL-35) is a member of interleukin12 family (Olson et al., 2013). It is also a cytokine which ensures the secretion of Treg cells and participates in inhibiting the functions and proliferation of T cells (Collison et al., 2010). Treg cells suppress the immune system cells through various mechanisms (Carvalho et al., 2019). It was proven that IL-35 is associated with tumor growth pathogenesis, progression of malignity, immunosuppression, and poor prognosis (Zeng et al., 2013; Liao et al., 2014; Hamidinia et al., 2015; Zhang et al., 2015). It was determined that IL-35 expression is higher in human mammary tumor tissues (Hamidinia et al., 2015; Hao et al., 2018). In another study, it was determined that the ratio of IL-23 and IL-35 (IL-23:IL-35) in the circulation decreases with the increase in the expressions of ki-67, p53 and EGFR, which are in the same family, in the human breast neoplasm tissue. According to this, it was concluded that IL-35 might be an important marker in the prognosis and progression of the disease (Hamidinia et al., 2015; Hao et al., 2018). When the literature on the given cytokine is reviewed, there is no sufficient literature in veterinary medicine. Carvalho et al. (2019) proved that high levels of IL -35 expressions are significantly associated with ulceration, formation of necrosis, histological grade of tumor, increased mitotic index, spread to lymph nodes, and aggressive tumor proliferation.

\section{COX-2 (Cyclooxygenase-2)}

Cox-2 participates in the formation of prostaglandins 
mediating events such as cellular proliferation, apoptosis, angiogenesis by taking part in arachidonic metabolism during tumorigenesis (Grosch et al., 2006). The studies conducted suggest that Cox-2 expression is associated with lymph node involvement and distant tissue metastasis (Lavalle et al., 2009; Queiroga et al., 2010). In canine mammary carcinomas, Cox-2 and ki-67 expressions are associated with poor prognosis and short survival time (Araújo et al., 2016). Besides, expression of Cox-2 and HER-2 in positive correlation indicates poor prognosis (Millanta et al., 2006). In these tumor cases where Cox-2 expression existence is observed, the use of piroxicam and meloxicam of Cox-2 inhibitors helps in the treatment by inhibiting angiogenesis and cellular proliferation (Knottenbelt et al., 2006). It is known that the use of piroxicam particularly in inflammatory carcinoma cases is very effective (Hugo et al., 2015). As a result, in addition to the use of Cox-2 expression as a good marker, its inhibitors have a great share in treatment.

\section{BRCA1/BRCA2 (Breast Cancer Type 1 and Type 2 Susceptibility Protein)}

Mutations in BRCA1 and BRCA2 genes are known to play a role in the growth of canine mammary tumors. In addition to its use as a biomarker, its use in the target treatment is another research subject. BRCA1 gene is observed in malignant tumors and BRCA2 gene is observed in both malignant tumors and benign tumors (Nieto et al., 2003; Rivera et al., 2009). In a study where BRCA2 mRNA levels were analyzed, reduced BRCA2 expression was detected in tumorous tissue when compared to healthy mammary tissue (Yoshikawa et al., 2015). On the other hand, Ripoli Lüder et al. (2016) compared healthy tissues, benign and malignant tissues, and no significant difference was detected between them. Due to the contradicting results in veterinary oncology, the mentioned gene mutations are still open to research. Its usability as a biomarker should be studied by future genome studies.

\section{Caspase-3}

Caspases are members of cysteine protease family, and they are one of the major effectors of apoptosis (Zapata et al., 1998; Degterev et al., 2003). Apoptosis begins with the extrinsic and intrinsic stimulation of caspases in mammals (Reed, 2000). Once caspases are activated, they may break up many cellular targets such as cytoskeleton proteins, oncoproteins and DNA repair system proteins. Active caspase-3 is particularly responsible for breakdown the DNA repair system. As it occurs in the cytoplasm of apoptotic cells, the assessment of active caspase3 allows detecting the early stage of apoptosis (Hadjiloucas et al., 2001). Besides, caspase-3 is accepted as an important indicator of morphological and biochemical changes associated with apoptosis (Degterev et al., 2003). In a study, caspase- 3 positive cells were detected at lower levels in malignant mammary tumors (Rodrigues et al., 2015). It also is noted that there is a statistically significant relation between mitotic index which confirms the disrupted balance between proliferation and apoptosis in canine mammary tumors (Vakkala et al., 1999; Huang et al., 2015; Dolka et al., 2016). Recently, caspase-3, which is a protein associated with apoptosis, has been used as a potential biomarker in human breast tumors (Kymionis et al., 2001; Yildirim et al., 2014). Therefore, as a result of the similarities between human breast tissues and canine mammary tissues, the use of caspase-3 as a biomarker in veterinary oncology should be clarified through future studies.

\section{B. Non invasive biomarkers}

\section{Urine}

\subsection{Spesific urine metabolites}

Valko-Rokytovska et al. (2020), unlike invasive approaches, paved the way for the use of noninvasive biomarkers and detected the levels of tyrosine (TYR), tryptophan (TRP) and their metabolites from urine collected through palpation from healthy patients and patients with mammary tumor after 12-hour fasting. The imbalances in TYR and TRP and their metabolites occur as a result of cancer, neurologic and inflammatory disorders (Oto et al., 2008; Wiggins et al., 2015; Heng et al., 2016). Serotonin (5-HT) which is one of the TRP metabolites is a mitogenic factor for cancer cells and participates in the autocrine cycle of growth factors. Besides, it 
contributes to the proliferation in aggressive tumors such as lung, bladder, and breast tumors (Jose et al., 2017). In addition to 5-HT, 5hydroxyindol acetic acid (5-HIAA), which is another metabolite, participates in the follow-up of disease progression and the assessment of treatment response (Nam et al., 2009). Kynurenic acid (KYNA) is known to have a dual role by allowing malignant cells escape the immune system agents or having an anti-proliferative effect on cancer cells (Sagan et al., 2015). 3,4dihydroxy-L-phenylalanine (L-DOPA) metabolizes into epinephrine and norepinephrine as a result of decarboxylation reaction (Valko-Rokytovska et al., 2020). Epinephrine participates in the formation of immunosuppressive microenvironment in mammary gland tumors in humans as well as some cancer types (Muthuswamy et al., 2017). At the end of the experiment, the values of epinephrine, L-DOPA, 5 -HIAA, indoxyl sulphate (IS), 5-HT, KYNA metabolites were found significantly high when compared to the control group. Although the tumors of the patients enrolled in the study were small, the metabolite levels were compared according to tumor size and tumor grade. The levels of E, L-DOPA, 5-HIAA and 5-HT metabolites were found highly significant in Grade 3 tumors. Results indicate that the metabolite level is not associated with tumor size. Similar to humans, the use of biomarkers in animals to distinguish diseases from normal individuals has a great importance. In this determination process, responses to process-related criteria such as proliferation, lifetime, chemotherapy response, etc. are sought through various invasive procedures such as various aspiration/biopsy and blood collection from the patient. The noninvasive biomarkers should have more extensive use because of the ease of application, and they should be developed by future studies.

\subsection{Neutrophil gelatinase-associted lipocalin and matrix metalloproteinase 9 complex}

Neutrophil gelatinase-associated lipocalin (NGAL) is expressed by neutrophils or different cells in cases such as tissue injuries (Kjeldsen et al., 2000). Besides, studies indicate that accumulation of NGAL is associated with the progression of the tumor (Fernandez et al., 2005; Provatopoulou et al., 2009). Three molecular forms of NGAL complexed with Matrix Metalloproteinase 9 (MMP9) are identified which are monomer (25$\mathrm{kDa}$ ), homodimer (45-kDa) and heterodimer (135kDa) (Chen et al., 2019). MMP9 is an enzyme which participates in the initiation, growth, metastasis, and progression of the tumor (Gialieli et al., 2011). In a study conducted on the role of NGAL in human breast tumor, increased MMP9 activity and NGAL/MMP9 complex formation was observed in the urine of mice with tumor cells expressing high levels of NGAL (Fernandez et al., 2005). Apart from human studies, the literature on NGAL expression and NGAL/MMP9 complex formation in tissue and urine in canine mammary tumor cases is not sufficient. Chen et al. (2019) detected the molecular form of NGAL/MMP9 both in tissue and urine samples of dogs with benign and malign mammary tumors, and they stated that this complex was not found in healthy dogs. They also indicated that NGAL/MMP9 complex was only found in the urine of dogs with mammary tumors.

\section{Saliva}

Saliva is a biological secretion which is systemically and locally used as a biomarker in the diagnosis of many diseases. As the sample collection is painless and easy and does not require an invasive procedure, it provides an important advantage to reduce sampling stress of patients (Cerón et al., 2019). In humans, it is concluded that the proteomic analysis of saliva is a successful technique in identifying the biomarkers associated with the disease in many pathologies such as cancer (Sivadasan et al., 2015). Tandem Mass Tag (TMT) which is one of the gel-free proteomic approaches was successfully used in pyometra cases that are gynecologically important in addition to certain infectious diseases in dogs (Franco-Martínez et al., 2020). When the current literature is reviewed, the first comparison of serum and saliva proteomics with gel-free TMT proteomic approach between mammary tumor cases in dogs which are gynecologically important and healthy dogs was conducted by Franco-Martínez et al. (2020). In salivation of patients with mammary 
tumor, S100A2, S100A4 and S100A6 from S100A protein are among the upregulated proteins. S100A proteins have a calcium binding role in many cancer types including the mammary tumors (Salama et al., 2008). In human mammary tumors, the positive correlation between S100A4 expression and cancer is proven with studies (Platt-Higgins et al., 2000; Rudland et al., 2000; Pedersen et al., 2002). S100A2 protein of the same family is considered to have a debatable role in carcinogenesis. This arises from its role both as a tumor suppressor and a promoter ( $\mathrm{Naz}$ et al., 2014; Zha et al., 2015). However, increased expression is significantly associated with short survival time in ovarium cancers (Giri et al., 2019). S100A6 expression is associated with poor prognosis in certain cancer types, and recent studies have shown that it is associated with good prognosis in human breast tumors (Zhang et al., 2017). The use of S100A family as a biomarker to assess the prognosis in canine mammary tumors should be supported with future studies. In the same study, the existence of proteins similar to calmodulin (CALM) in salivation of dogs with mammary tumors was also presented (FrancoMartínez et al., 2020). While CALM2 and CALM3 showed up-regulation, KLK1 showed downregulation. Both kallikrein genes and proteins have an effect of inducing and inhibiting tumor cell angiogenesis, metastasis, and the growth of these tumor cells through various mechanism (Borgoño et al., 2004). Therefore, the role of kallikrein genes and proteins in cancer is controversial. There was no significant difference between the proteomic results of serum and salivation when they were compared in the study. However, it was determined that the proteins in salivation were twice as much of those in serum, and none of the proteins was detected together both in serum and salivation. This indicates that proteins originate from different locations. Besides, it is determined that the proteins occur in the salivation are not carried in the blood; and they originate from salivary glands, nasal or bronchial secretion, and gingival crevicular fluid. Thus, salivation may be presented as a noninvasive biomarker when it is supported with further studies.

\section{Conclusion}

In human and veterinary oncology, it is very important to identify biomarkers which may distinguish healthy individuals from unhealthy ones. In veterinary medicine, there are many studies on the canine mammary tumor biomarkers. Despite this, the ideal biomarker has not yet been concluded. An ideal biomarker should bear minimum risk for the patient during application; it should have positive correlation with the malignity; and it should give a definite result about the prognosis. With the recent studies, non-invasive biomarkers which may be measured from bodily fluids such as salivation are added to biomarkers such as tissue which require an invasive procedures during sampling. Invasive biomarkers provide information on many criteria such as diagnosis, cellular differentiation, ulceration and necrosis formation, prognosis of the patient, histological grade of tumor, high mitotic index, spread to lymph nodes, and survival time. Non-invasive approaches provide benefits for the follow-up of the diseases with the imbalances in the systems. Higher expression of specific urine metabolites, which is one of these biomarkers, in patients with mammary tumors compared to healthy individuals may be considered as a beneficial biomarker for diagnosis. Salivation, which is another noninvasive biomarker, may be accepted as a potential biomarker although it is quite new. When non-invasive biomarkers are considered, they are promising but their usability should be supported by future studies.

Conflict of Interest: Authors declare that there is no conflict of interest.

\section{References}

Alenza, M. P., Pena, L., Castillo, N. D., \& Nieto, A. I. (2000). Factors influencing the incidence and prognosis of canine mammary tumours. Journal of Small Animal Practice, 41(7), 287-291.

Almeida, J. R. C., Pedrosa, N. L., Leite, J. B., Fleming, T. R., Carvalho, V. H., \& Cardoso, A. A. (2007). Tumor markers: A literature review. Revista Brasileira de Cancerologia, 53(3), 305-316.

Andrews, J. L., Kim, A. C., \& Hens, J. R. (2012). The role and function of cadherins in the mammary gland. Breast Cancer Research, 14(1), 1-10. 
Araújo, M. R., Campos, L. C., Damasceno, K. A., Gamba, C. O., Ferreira, E., \& Cassali, G. D. (2016). HER-2, EGFR, Cox-2 and Ki67 expression in lymph node metastasis of canine mammary carcinomas: association with clinical-pathological parameters and overall survival. Research in Veterinary Science, 106, 121-130.

Asproni, P., Ressel, L., Millanta, F., Vannozzi, I., \& Poli, A. (2015). Co-localization of PTEN and E-cadherin in canine mammary hyperplasias and benign and malignant mammary tumors. Research in Veterinary Science, 103, 113-118.

Bakthisaran, R., Tangirala, R., \& Rao, C. M. (2015). Small heat shock proteins: role in cellular functions and pathology. Biochimica et Biophysica Acta Molecular Cell Reserach, 1854(4), 291-319.

Baranwal, S., \& Alahari, S. K. (2009). Molecular mechanisms controlling E-cadherin expression in breast cancer. Biochemical and Biophysical Research Communications, 384(1), 6-11.

Benavente, M. A., Bianchi, C. P., \& Aba, M. A. (2016). Canine mammary tumors: risk factors, prognosis and treatments. Journal of Animal and Veterinary Advances, 6(8), 1291-1300.

Beauvais, W., Cardwell, J. M., \& Brodbelt, D. C. (2012). The effect of neutering on the risk of mammary tumours in dogs-a systematic review. The Journal of Small Animal Practice, 53(6), 314-322.

Ben-Baruch, A. (2002). Host microenvironment in breast cancer development: inflammatory cells, cytokines and chemokines in breast cancer progression: reciprocal tumor-microenvironment interactions. Breast Cancer Research, 5(1), 31.

Benavente, M. A., Bianchi, C. P., \& Aba, M. A. (2019). Expression of oxytocin receptors in canine mammary tumours. Journal of Comparative Pathology, 170, 26-33.

Benavente, M. A., Bianchi, C. P., Imperiale, F., \& Aba, M. A. (2016). Antiproliferative effects of oxytocin and desmopressin on canine mammary cancer cells. Frontiers in Veterinary Science, 3(2), 119.

Bergman, I. (2012). The significance of oxytocin in canine mammary tumours. Master thesis, Swedish University, Uppsala.

Boggs, R. M., Wright, Z. M., Stickney, M. J., Porter, W. W., \& Murphy, K. E. (2008). MicroRNA expression in canine mammary cancer. Mammalian Genome, 19 (7-8), 561-569.

Boller, K., Vestweber, D., \& Kemler, R. (1985). Celladhesion molecule uvomorulin is localized in the intermediate junctions of adult intestinal epithelial cells. The Journal of Cell Biology, 100(1), 327-332.

Borgoño, C. A., \& Diamandis, E. P. (2004). The emerging roles of human tissue kallikreins in cancer. Nature Reviews Cancer, 4(11), 876-890.

Bravo, R., \& Celis, J. E. (1980). A search for differential polypeptide synthesis throughout the cell cycle of HeLa cells. The Journal of Cell Biology, 84(3), 795802.

Brunetti, B., Sarli, G., Preziosi, R., Leprotti, S., \& Benazzi, C. (2003). E-cadherin expression in canine mammary carcinomas with regional lymph node metastases. Journal of Veterinary Medicine. A Physiology, Pathology, Clinical Medicine, 50(10), 496 -500 .

Bulkowska, M., Rybicka, A., Senses, K. M., Ulewicz, K., Witt, K., Szymanska, J., ... \& Krol, M. (2017). MicroRNA expression patterns in canine mammary cancer show significant differences between metastatic and non-metastatic tumours. BioMed Central Cancer, 17(1), 728.

Campos, L. C., Lavalle, G. E., Estrela-Lima, A., Melgaço de Faria, J. C., Guimarães, J. E., Dutra, A. P., ... \& Cassali, G. D. (2012). CA 15.3, CEA and LDH in dogs with malignant mammary tumors. Journal of Veterinary Internal Medicine, 26(6), 1383-1388.

Canadas-Sousa, A., Santos, M., Leal, B., Medeiros, R., \& Dias-Pereira, P. (2019). Estrogen receptors genotypes and canine mammary neoplasia. BioMed Central Veterinary Research, 15(1), 325.

Cardoso, F., Saghatchian, M., \& Thompson, A. (2008). Inconsistent criteria used in american society of clinical oncology 2007 update of recommendations for the use of tumor markers in breast cancer. Journal of Clinical Oncology, 26(12), 20582059.

Carvalho, M. I., Guimarães, M. J., \& Pires, I. et al. (2013). EGFR and microvessel density in canine malignant mammary tumours. Research in Veterinary Science, 95(3), 1094-1099.

Carvalho, M. I., Pires, I., Prada, J., Lobo, L., \& Queiroga, F. L. (2016). Ki-67 and PCNA expression in canine mammary tumors and adjacent nonneoplastic mammary glands: prognostic Impact by a multivariate survival analysis. Veterinary Pathology, 53(6), 1138-1146.

Carvalho, M. I., Pires, I., Prada, J., Pinto, C., Gregorio, H., Cogliati, B. \& Queiroga, F. L. (2019). Assessing the interleukin 35 ımmunoexpression in malignant canine mammary tumors: association with clinicopathological parameters and prognosis. Anticancer Research, 39(4), 2077-2083. 
Cassoni, P., Sapino, A., Marrocco, T., Chini, B., \& Bussolati, G. (2004). Oxytocin and oxytocin receptors in cancer cells and proliferation. Journal of Neuroendocrinology, 16(4), 362-364.

Cawthorn, T. R., Moreno, J. C., Dharsee, M., TranThanh, D., Ackloo, S., Hong Zhu, P., ... \& Done, S. J. (2012). Proteomic analyses reveal high expression of decorin and endoplasmin (HSP90B1) are associated with breast cancer metastasis and decreased survival. Public Library of Science, 7(2), e30992.

Celis, J. E., \& Celis, A. (1985). Cell cycle-dependent variations in the distribution of the nuclear protein cyclin proliferating cell nuclear antigen in cultured cells: subdivision of $S$ phase. Proceedings of the National Academy of Science of the United States of America, 82(10), 3262-3266.

Cerón, J. J. (2019). Acute phase proteins, saliva and education in laboratory science: an update and some reflections. BMC Veterinary Research, 15(1), 1 $-8$.

Chan, K. K., Matchett, K. B., McEnhill, P. M., Dakir, E. H., McMullin, M. F., El-Tanani, Y., ... \& El-Tanani, M. (2015). Protein deregulation associated with breast cancer metastasis. Cytokine \& Growth Factor Reviews, 26(4), 415-423.

Chang, C. C., Tsai, M. H., Liao, J. W., Chan, J. P. W., Wong, M. L., \& Chang, S. C. (2009). Evaluation of hormone receptor expression for use in predicting survival of female dogs with malignant mammary gland tumors. Journal of American Veterinary Medical Association, 235(4), 391-396.

Changkija, B., \& Konwar, R. (2012). Role of interleukin10 in breast cancer. Breast Cancer Research and Treatment, 133(1), 11-21.

Chen, Y. C., Chang, S. C., Huang, Y. H., Lee Y. J., Chang, C. C., Liao J. W., \& Hsu, W. L. (2019). Expression and the molecular forms of neutrophil gelatinaseassociated lipocalin and matrix metalloproteinase 9 in canine mammary tumours. Veterinary and Comparative Oncology, 17(3), 427-438.

Chmielewska-Krzesińska, M., Jakimiuk, A., \& Wąsowicz, K. (2019). Stability of $\alpha B$-crystallin gene expression in canine mammary gland neoplasms. Should it be considered as circulating tumor cell genetic marker?. Polish Journal of Veterinary Science, 22(3), 523-529.

Choi, U. S., \& Kim, D. Y. (2011). Immunocytochemical detection of Ki-67 in Diff-Quik-stained cytological smears of canine mammary gland tumours. Cytopathology, 22(2), 115-120.

Chou, J., Lin, J. H., Brenot, A., Kim, J. W., Provot, S., \&
Werb, Z. (2013). GATA3 suppresses metastasis and modulates the tumour microenvironment by regulating microRNA-29b expression. Nature Cell Biology, 15(2), 201-213.

Collison, L. W., Chaturvedi, V., Henderson, A. L., Giacomin, P. R., Guy, C., Bankoti, J., ... \& Vignali, D. A. A. (2010). IL-35-mediated induction of a potent regulatory T cell population. Nature Immunology, 11 (12), 1093-1101.

Dantas Cassali, G., Cavalheiro Bertagnolli, A., Ferreira, E., Damasceno K. A., Gamba, C. O., \& de Campos, C. B. (2012). Canine mammary mixed tumours: a review. Veterinary Medicine International, 48(1), 117-131.

Da Costa, A., Oliveira, J. T., Gärtner, F., Kohn, B., Gruber, A. D., \& Klopfleisch, R. (2011). Potential markers for detection of circulating canine mammary tumor cells in the peripheral blood. The Veterinary Journal, 190(1), 165-168.

de Andrés, P. J., Illera, J. C., Cáceres, S., Díez, L., PérezAlenza, M. D., \& Peña, L. (2013). Increased levels of interleukins 8 and 10 as findings of canine inflammatory mammary cancer. Veterinary Immunology and Immunopathology, 152(3-4), 245251.

De Las Mulas, J. M., Millán, Y., \& Dios, R. (2005). A prospective analysis of immunohistochemically determined estrogen receptor $\alpha$ and progesterone receptor expression and host and tumor factors as predictors of disease-free period in mammary tumors of the dog. Veterinary Pathology, 42(2), 200212.

Degterev, A., Boyce, M., \& Yuan, J. (2003). A decade of caspases. Oncogene, 22(53), 8543-8567.

Deocaris, C. C., Kaul, S. C., \& Wadhwa, R. (2006). On the brotherhood of the mitochondrial chaperones mortalin and heat shock protein 60. Cell Stress Chaperones, 11(2), 116.

Dolka, I., Król, M., \& Sapierzyński, R. (2016). Evaluation of apoptosis-associated protein (Bcl-2, Bax, cleaved caspase-3 and p53) expression in canine mammary tumors: An immunohistochemical and prognostic study. Research in Veterinary Science, 105, 124-133.

Dutra, A. P., Granja, N. V. M., Schmitt, F. C., \& Cassali, G. D. (2004). c-erbB-2 expression and nuclear pleomorphism in canine mammary tumors. Brazilian Journal of Medical and Biological Research, 37(11), 1673-1681.

Ellis, R. J., Van der Vies, S. M. (1991). Molecular chaperones. Annual Review of Biochemistry, 60(1), 321-347. 
Endl, E., Kausch, I., Baack, M., Knippers, R., Gerdes, J., \& Scholzen, T. (2001). The expression of Ki-67, MCM3, and p27 defines distinct subsets of proliferating, resting, and differentiated cells. The Journal of Pathology, 195(4), 457-462.

Estrela-Lima, A., Araújo, M. S. S., Soares, R. P., Ribeiro, L. G. R., Damasceno, K. A., Costa, A. T., ... \& Cassali, G. D. (2016). Plasma Biomarkers Profile of female dogs with mammary carcinoma and its association with clinical and pathological features. Veterinary and Comparative Oncology, 14(1), 88-100.

Fernandes, J. V., Cobucci, R. N.O., Jatobá, C. A. N., de Medeiros Fernandes, T. A. A., de Azevedo, J. W. V., \& de Araújo, J. M. G. (2015). The role of the mediators of inflammation in cancer development. Pathology \& Oncology Research, 21 (3), 527-534.

Fernández, C. A., Yan, L, Louis, G., Yang, J., Kutok, J. L., \& Moses, M. A. (2005). The matrix metalloproteinase-9/neutrophil gelatinaseassociated lipocalin complex plays a role in breast tumor growth and is present in the urine of breast cancer patients. Clinical Cancer Research, 11(15), 5390-5395.

Franco-Martínez, L., Gelemanović, A., Horvatić, A., Contreras-Agullar, M. D., Dabrowski, R., Mrijak, V., ... \& Tvarijonaviciute, A. (2020). Changes in Serum and Salivary Proteins in Canine Mammary Tumors. Animals, 10(4), 741.

Franco-Martínez, L., Horvatić, A., Gelemanović, A., Samardzija, M., Mrljak, V., Contreras-Aguilar, M. D., ... \& Tvarijonaviciute, A. (2020). Changes in the salivary proteome associated with canine pyometra. Frontiers in Veterinary Science, 7, 277.

Ferreira, E., Bertagnolli, A. C., Cavalcanti, M. F., Schmitt, F. C., \& Cassali, G. D. (2009). The relationship between tumour size and expression of prognostic markers in benign and malignant canine mammary tumours. Veterinary and Comparative Oncology, 7(4), 230-235.

Gama, A., Alves, A., \& Schmitt, F. (2008). Identification of molecular phenotypes in canine mammary carcinomas with clinical implications: application of the human classification. Virchows Archiv, 453(2), 123-132.

Gama, A., Gärtner, F., Alves, A., \& Schmitt, F. (2009). Immunohistochemical expression of Epidermal Growth Factor Receptor (EGFR) in canine mammary tissues. Research in Veterinary Science, 87(3), 432437.

Gama, A., Paredes, J., Gärtner, F., Alves, A., \& Schmitt, F. (2008). Expression of E-cadherin, P-cadherin and $\beta$-catenin in canine malignant mammary tumours in relation to clinicopathological parameters, proliferation and survival. The Journal of Veterinary Science, 177(1), 45-53.

Gasco, M., Shami, S., \& Crook, T. (2002). The p53 pathway in breast cancer. Breast Cancer Research, 4 (2), 70.

Geddes, D. T. (2007). Inside the lactating breast: the latest anatomy research. Journal of Midwifery \& Women's Health, 52(6), 556-563.

Gialeli, C., Theocharis, A. D., Karamanos, N. K. (2011). Roles of matrix metalloproteinases in cancer progression and their pharmacological targeting. The FEBS Journal, 278(1), 16-27.

Giri, K., Mehta, A., \& Ambatipudi, K. (2019). In search of the altering salivary proteome in metastatic breast and ovarian cancers. The FASEB Journal. 1(3), 191-207.

Goldschmidt, M., Peña, L., Rasotto, R., \& Zappulli, V. (2011). Classification and grading of canine mammary tumors. Veterinary Pathology, 48(1), 117131.

Goplen, D., Bougnaud, S., Rajcevic, U. Bøe, S. O., Skaftnesmo, K. O., Voges, J., ... \& Bjerkvig, R. (2010). $\alpha \mathrm{B}$-crystallin is elevated in highly infiltrative apoptosis-resistant glioblastoma cells. The American Journal of Pathology, 177(4), 1618-1628.

Grösch, S., Maier, T. J., Schiffmann, S., \& Geisslinger, G. (2006). Cyclooxygenase-2 (COX-2) independent anticarcinogenic effects of selective COX-2 inhibitors. Journal of the National Cancer Institute, 98(11), 736-747.

Guimarães, M. J., Carvalho, M. I., Pires, I., Prada, J., Gil Gonzalez, A., Lopes, C., \& Queiroga, F. L. (2014). Concurrent expression of cyclo-oxygenase-2 and epidermal growth factor receptor in canine malignant mammary tumours. Journal of Comparative Pathology, 150(1), 27-34.

Hadjiloucas, I., Gilmore, A. P., Bundred, N. J., \& Streuli, C. H. (2001). Assessment of apoptosis in human breast tissue using an antibody against the active form of caspase 3: relation to tumour histopathological characteristics. British Journal of Cancer, 85(10), 1522-1526.

Hamidinia, M., Boroujerdnia, M. G., Talaiezadeh, A., Solgi, G., Roshani, R., Iranprast, S., \& Khodadadi, A. (2015). Increased P-35, EBI3 transcripts and other treg markers in peripheral blood mononuclear cells of breast cancer patients with different clinical stages. Advanced Pharmaceutical Bulletin, 5(2), 261. 
Hao, S., Chen, X., Wang, F., Shao, Q., Liu, J., Zhao, H., ... \& Mao, H. (2018). Breast cancer cell-derived IL-35 promotes tumor progression via induction of IL-35producing induced regulatory $T$ cells. Carcinogenesis, 39(12), 1488-1496.

Harris, L., Fritsche, H., Mennel, R., Norton, L., Ravdin, P., Somerfield, S. T. R., ... (2007). American Society of Clinical Oncology 2007 update of recommendations for the use of tumor markers in breast cancer. Journal of Clinical Oncology, 25(33), 5287-5312.

Hayes, D. F., Sekine, H., Ohno, T., Abe, M., Keefe, K., \& Kufe, D. W. (1985). Use of a murine monoclonal antibody for detection of circulating plasma DF3 antigen levels in breast cancer patients. Journal of Clinical Investigation, 75(5), 1671-1678.

Heimann, R., Lan, F., McBride, R., \& Hellman, S. (2000). Separating favorable from unfavorable prognostic markers in breast cancer: the role of $\mathrm{E}$ cadherin. Cancer Research, 60(2), 298-304.

HellmÉn, E. (1992). Characterization of four in vitro established canine mammary carcinoma and one atypical benign mixed tumor cell lines. In Vitro Cellular \& Developmental Biology Animal, 28(5), 309 $-319$.

Heng, B., Lim, C. K., Lovejoy, D. B., Bessede, A., Gluch, L., Guillemin, G. J. (2016). Understanding the role of the kynurenine pathway in human breast cancer immunobiology. Oncotarget, 7(6), 6506.

Hsu, W. L., Huang, H. M., Liao, J. W., Wong, M. L., \& Chang, S. C. (2009). Increased survival in dogs with malignant mammary tumours overexpressing HER-2 protein and detection of a silent single nucleotide polymorphism in the canine HER-2 gene. Journal of Veterinary Science, 180(1), 116-123.

Huang, C., Wang, X., Sun, B., Li, M., Zhao, X., Gu, Y., ... \& Li, Y. (2015). Study on mouse model of triplenegative breast cancer: association between higher parity and triple-negative breast cancer. Target Oncology, 10(1), 85-97.

Hugo, H. J., Saunders, C., Ramsay, R. G., Thompson, E. W. (2015). New insights on COX-2 in chronic inflammation driving breast cancer growth and metastasis. Journal of Mammary Gland Biology and Neoplasia, 20(3-4), 109-119.

Ikeda, E., Achen, M. G., Breier, G., \& Risau, W. (1995). Hypoxia-induced transcriptional activation and increased mRNA stability of vascular endothelial growth factor in C6 glioma cells. Journal of Biological Chemistry, 270(34), 19761-19766.

Iorio, M. V., Ferracin, M., Liu, C. G., Veronese, A., Spizzo, R., Sabbioni, S., ... \& Croce, C. M. (2005). MicroRNA gene expression deregulation in human breast cancer. Cancer Research, 65(16), 7065-7070.

Jose, J., Tavares, C. D., Ebelt, N. D., Lodi, A., Edupuganti, R., Xie, X., ... \& Dalby, K. N. (2017). Serotonin analogues as inhibitors of breast cancer cell growth. ACS Medicinal Chemistry Letters, 8(10), 1072-1076.

Jurikova, M., Danihel, L'., Polák, Š., Varga, I. (2016). Ki67, PCNA, and MCM proteins: Markers of proliferation in the diagnosis of breast cancer. Acta Histochemica, 118(5), 544-552.

Kaszak, I., Ruszczak, A., Kanafa, S., Kacprzak, K., Król, M., \& Jurka, P. (2018). Current biomarkers of canine mammary tumors. Acta Veterinaria Scandinavica, 60(1), 1-13.

Kausitz, J., Altaner, C., Boljesikova, E., \& Spanik, S. (2003). Tumor markers (Nadorove markery). In: Oncology (Onkologia), VEDA, eds., Bratislava, Slovenskej ' akademie vied. 119-124.

Kim, J. H., Yu, C. H., Yhee, J. Y., Im, K. S., \& Sur, J. H. (2010). Lymphocyte infiltration, expression of interleukin (IL)-1, IL-6 and expression of mutated breast cancer susceptibility gene-1 correlate with malignancy of canine mammary tumours. Journal of Comparative Pathology, 142(2-3), 177-186.

Kjeldsen, L., Cowland, J. B., \& Borregaard, N. (2000). Human neutrophil gelatinase-associated lipocalin and homologous proteins in rat and mouse. Biochimica et Biophysica Acta, 1482(1-2), 272-283.

Knottenbelt, C., Chambers, G., Gault, E., \& Argyle, D. J. (2006). The in vitro effects of piroxicam and meloxicam on canine cell lines. Journal of Small Animal Practice, 47(1), 14-20.

Kumar, B. S., Bhardwaj, R., Mahajan, K., Kashyap, N., Kumar, A., \& Verma, R. (2018). The overexpression of Hsp90B1 is associated with tumorigenesis of canine mammary glands. Molecular and Cellular Biochemistry, 440(1-2), 23-31.

Kymionis, G. D., Dimitrakakis, C. E., Konstadoulakis, M. M., Arzimanoglou, I., Leandros, E., Chalkiadakis, G., ... \& Michalas, S. (2001). Can expression of apoptosis genes, bcl-2 and bax, predict survival and responsiveness to chemotherapy in node-negative breast cancer patients?. Journal of Surgical Research, 99(2), 161-168.

Lana, S. E., Rutteman, G. R., \& Withrow, S. J (2007). Tumors of the mammary gland. In: Withrow \& MacEwen's small animal clinical oncology. Withrow SJ, Vail DM (Ed), 619-638, Saunders Elsevier, Missouri.

Lavalle, G. E., Bertagnolli, A. C., Tavares, W. L. F., \& Cassali, G. D. (2009). Cox-2 expression in canine mammary carcinomas: correlation with 
angiogenesis and overall survival. Veterinary Pathology, 46(6), 1275-1280.

Ławicki, S., Zajkowska, M., Głażewska, E. K., Będkowska, G. E., \& Szmitkowski, M. (2017). Plasma levels and diagnostic utility of VEGF, MMP-2 and TIMP-2 in the diagnostics of breast cancer patients. Biomarkers, 22(2), 157-164.

Ledecky, V., Valencakova-Agyagosova, A., Lepej, J., Frischova, Z., Hornak, S., \& Nagy, V. (2013). Determination of carcinoembryonic antigen and cancer antigen values with the radioimmunoassay method in healthy females dogs. Veterinary Medicine-Czech, 58(5), 277-283.

Lee, A. S. (2014). Glucose-regulated proteins in cancer: molecular mechanisms and therapeutic potential. Nature Reviews Cancer, 14(4), 263-276.

Lee, C. H., Kim, W. H., Lim, J. H., Kang, M. S., Kim, D. Y., \& Kweon, O. K. (2004). Mutation and overexpression of p53 as a prognostic factor in canine mammary tumors. Journal of Veterinary Science, 5(1), 63-70.

Liao, K. L., Bai, X. F., \& Friedman, A. (2014). Mathematical modeling of Interleukin-35 promoting tumor growth and angiogenesis. Public Library of Science One, 9(10), e110126.

Lin, W. W., \& Karin, M. (2007). A cytokine-mediated link between innate immunity, inflammation, and cancer. Journal of Clinical Investigation, 117 (5), 1175-1183.

Liu, B., Earl, H. M., Baban, D., Shoaibi, M., Fabra, A., Kerr, D. J., \& Seymour, L. W. (1995). Melanoma cell lines express VEGF receptor KDR and respond to exogenously added VEGF. Biochemical and Biophysical Research Communications, 217(3), 721727.

Łopuszyński, W., Szczubiał, M., \& Komsta, R. (2010). Prognostic status of $p 53$ protein accumulation in canine malignant mammary tumours. Bulletin of the Veterinary Institute Pulawy, 54, 105-111.

Löhr, C. V., Teifke, J. P., Failing, K., \& Weiss, E. (1997). Characterization of the proliferation state in canine mammary tumors by the standardized AgNOR method with postfixation and immunohistologic detection of Ki-67 and PCNA. Veterinary Pathology, 34(3), 212-221.

Lutful Kabir, F. M., Delnnocentes, P., \& Bird, R. C. (2015). Altered microRNA expression profiles and regulation of INK4A/CDKN2A tumor suppressor genes in canine breast cancer models. Journal of Cellular Biochemistry, 116(12), 2956-2969.

Lüder Ripoli, F., Conradine Hammer, S., Mohr, A., Willenbrock, S., Hewicker-Trautwein, M., Brenig, B., ... \& Nolte, I. (2016). Multiplex Gene Expression
Profiling of 16 Target Genes in Neoplastic and NonNeoplastic Canine Mammary Tissues Using Branched-DNA Assay. International Journal of Molecular Sciences, 17(9), 1589.

Lüftner, D., Lüke, C., \& Possinger, K. (2003). Serum HER $-2 /$ neu in the management of breast cancer patients. Clinical Biochemistry, 36(4), 233-240.

Malin, D., Petrovic, V., Strekalova, E., Sharma, B., \& Cryns, V. L. (2016). aB-crystallin: Portrait of a malignant chaperone as a cancer therapeutic target. Pharmacology \& Therapeutics, 160, 1-10.

Malin, D., Strekalova, E., \& Petrovic, V. (2014). aBcrystallin: a novel regulator of breast cancer metastasis to the brain. Clinical Cancer Research, 20 (1), 56-67.

Manuali, E., De Giuseppe, A., \& Feliziani, F. (2012). CA 15-3 cell lines and tissue expression in canine mammary cancer and the correlation between serum levels and tumour histological grade. BMC Veterinary Research, 8(1), 86.

Martins, G. R., Gelaleti, G. B., Moschetta, M. G., Maschio-Signorini, L. B., Zuccari, D. A., de Campos, P. (2016). Proinflammatory and anti-inflammatory cytokines mediated by NF-KB factor as prognostic markers in mammary tumors. Mediators of Inflammation, 2016:9512743.

Matos, A. J. F., Lopes, C., Carvalheira, J., Santos, M., Rutteman, G. R., \& Gärtner, F. (2006). E-cadherin expression in canine malignant mammary tumours: relationship to other clinico-pathological variables. Journal of Comparative Pathology, 134(23), 182-189.

Merendino, R. A., Arena, A., Capozza, A. B., Chillemi, S., \& Mesiti, M. (1996). Serum levels of interleukin-10 in patients affected by breast cancer. Immunology Letters, 53(1), 59.

Millanta, F., Calandrella, M., Bari, G., Niccolini, M., Vannozzi, I., \& Poli, A. (2005). Comparison of steroid receptor expression in normal, dysplastic, and neoplastic canine and feline mammary tissues. Research in Veterinary Science, 79(3), 225232.

Millanta, F., Citi, S., Della Santa, D., Porciani, M., \& Poli, A. (2006). COX-2 expression in canine and feline invasive mammary carcinomas: correlation with clinicopathological features and prognostic fmolecular markers. Breast Cancer Research Treatment, 98(1), 115-120.

Molina, R., Barak, V., van Dalen, A., Duffy, M. J., Einarsson, R., Gion, M., ... \& Stieber, P. (2005). Tumor markers in breast cancer-European Group on Tumor Markers recommendations. Tumor Biology, 26(6), 281-293. 
Morris, J. S., Dobson, J. M., \& Bostock, D. E. (1993). Use of tamoxifen in the control of canine mammary neoplasia. Veterinary Record, 133(22), 539.

Muthuswamy, R., Okada, N. J., Jenkins, F. J., McGuire, K., McAuliffe, P. F., Zeh, H. J., ... \& Kalinski, P. (2017). Epinephrine promotes COX-2-dependent immune suppression in myeloid cells and cancer tissues. Brain, Behavior and Immunity, 62, 78-86.

Nam, H., Chung, B. C., Kim, Y., Lee, K., \& Lee, D. (2009). Combining tissue transcriptomics and urine metabolomics for breast cancer biomarker identification. Bioinformatics, 25(23), 3151-3157.

Nami, B., Ghasemi-Dizgah, A., \& Vaseghi, A. (2016). Overexpression of molecular chaperons GRP78 and GRP94 in CD44hi/CD24lo breast cancer stem cells. Biolmpacts, 6(2), 105.

Naz, S., Bashir, M., Ranganathan, P., Bodapati, P., Santosh, V., \& Kondaiah, P. (2014). Protumorigenic actions of S100A2 involve regulation of PI3/Akt signaling and functional interaction with Smad3. Carcinogenesis, 35(1), 14-23.

Neumann, S., Schuettler, J., Frenz, M., Kaup, F. J., \& Gessler, F. (2017). Investigation of serum Ki-67 as a biomarker in tumor-bearing dogs. Research in Veterinary Science, 110, 16-21.

Newman, G., \& Gonzalez-Perez, R. R. (2014). Leptincytokine crosstalk in breast cancer. Molecular and Cellular Endocrinology, 382(1), 570-582.

Nicolini, A., Carpi, A., \& Rossi, G. (2006). Cytokines in breast cancer. Cytokine \& Growth Factor Reviews, 17(5), 325-337.

Nieto, A., Pena, L., Pérez-Alenza, M. D., Sanchez, M. A., Flores, J. M., \& Castano, M. (2000). Immunohistologic detection of estrogen receptor alpha in canine mammary tumors: clinical and pathologic associations and prognostic significance. Veterinary Pathology, 37(3), 239-247.

Nieto, A., Perez-Alenza, M. D., Del Castillo, N., Tabanera, E., Castano, M., \& Pena, L. (2003). BRCA1 expression in canine mammary dysplasias and tumours: relationship with prognostic variables. Journal of Comparative Pathology, 128(4), 260-268.

Nowak, M., Madej, J. A., Pula, B., Dziegiel, P., \& Ciaputa, R. (2015). Expression of matrix metalloproteinase 2 (MMP-2), E-cadherin and Ki-67 in metastatic and non-metastatic canine mammary carcinomas. Irish Veterinary Journal, 69 (1), 9.

O'Day, E., \& Lal, A. (2010). MicroRNAs and their target gene networks in breast cancer. Breast Cancer Research, 12(2), 1-10.

Olson, B. M., Jankowska-Gan, E., Becker, J. T., Vignali, D. A., Burlingham, W. J., \& McNeel, D. G. (2012).
Human prostate tumor antigen-specific CD8+ regulatory $\mathrm{T}$ cells are inhibited by CTLA-4 or IL-35 blockade. Journal of Immunology, 189(12), 55905601.

Oto, J., Suzue, A., Inui, D., Fukuta, Y., Hosotsubo, K., Torii, M., ... \& Nishimura M. (2008). Plasma proinflammatory and anti-inflammatory cytokine and catecholamine concentrations as predictors of neurological outcome in acute stroke patients. Journal of Anesthesia, 22(3), 207-212.

Pedersen, K. B., Nesland, J. M., Fodstad, Ø., \& Mælandsmo, G. M. (2002). Expression of S100A4, Ecadherin, $\alpha$-and $\beta$-catenin in breast cancer biopsies. British Journal of Cancer, 87(11), 12811286.

Pena, L. L., Nieto, A. I., Pérez-Alenza, D., Cuesta, P., \& Castano, M. (1998). Immunohistochemical detection of Ki-67 and PCNA in canine mammary tumors: relationship to clinical and pathologic variables. Journal of Veterinary Diagnostic Investigation, 10(3), 237-246.

Perey, L., Hayes, D. F., Maimonis, P., Abe, M., O'Hara, C., \& Kufe, D. W. (1992). Tumor selective reactivity of a monoclonal antibody prepared against a recombinant peptide derived from the DF3 human breast carcinoma-associated antigen. Cancer Research, 52(9), 2563-2568.

Plaks, V., Koopman, C. D., \& Werb, Z. (2013). Circulating tumor cells. Science, 341(6151), 11861188.

Platt-Higgins, A. M., Renshaw, C. A., West, C. R., Winstanley, J. H., De Silva Rudland, S., Barraclough, R., \& Rudland, P. S. (2000). Comparison of the metastasis-inducing protein S100A4 (p9ka) with other prognostic markers in human breast cancer. International Journal of Cancer, 89(2), 198208.

Provatopoulou, X., Gounaris, A., Kalogera, E., Zagouri, F., Flessas, I., Goussetis, E., ... \& Zografos, G. (2009). Circulating levels of matrix metalloproteinase-9 (MMP-9), neutrophil gelatinase-associated lipocalin (NGAL) and their complex MMP-9/NGAL in breast cancer disease. BMC Cancer, 9(1), 1-7.

Queiroga, F. L., Pérez-Alenza, D., González-Gil, A., Silván, G., Peña, L., \& Illera, J. C. (2015). Serum and tissue steroid hormone levels in canine mammary tumours: clinical and prognostic implications. Reproduction in Domestic Animals, 50 (5), 858-865.

Queiroga, F. L., Perez-Alenza, M. D., González-Gil, A., Silván, G., Peña, L., \& Illera, J. C. (2017). Quantification of epidermal growth factor receptor (EGFR) in canine mammary tumours by ELISA assay: 
clinical and prognostic implications. Veterinary and Comparative Oncology, 15(2), 383-390.

Queiroga, F. L., Pires, I., Lobo, L., \& Lopes, C. S. (2010). The role of Cox-2 expression in the prognosis of dogs with malignant mammary tumours. Research in Veterinary Science, 88(3), 441-445.

Queiroga, F. L., Pires, I., Parente, M., Gregório, H., \& Lopes, C. S. (2011). COX-2 over-expression correlates with VEGF and tumour angiogenesis in canine mammary cancer. The Veterinary Journal, 189(1), 77-82.

Peña, L., Gama, A., Goldschmidt, M. H., Abadie, J., Benazzi, C., Castagnaro, M., ... \& Martín de las Mulas, J. (2014). Canine mammary tumors: a review and consensus of standard guidelines on epithelial and myoepithelial phenotype markers, HER2, and hormone receptor assessment using immunohistochemistry. Veterinary Pathology, 51(1), 127-145.

Reed, J. C. (2000). Mechanisms of apoptosis. The American Journal of Pathology, 157(5), 1415-1430.

Restucci, B., Papparella, S., Maiolino, P., \& De Vico, G. (2002). Expression of vascular endothelial growth factor in canine mammary tumors. Veterinary Pathology, 39(4), 488-493.

Rivera, P., Melin, M., Biagi, T., Fall, T., Haggström, J., Lindblad-Toh, K., von Euler, H. (2009). Mammary tumor development in dogs is associated with BRCA1 and BRCA2. Cancer Research, 69(22), 87708774.

Rodrigues, H., Carvalho, M. I., Pires, I., Prada, J., \& Queiroga, F. L. (2016). Clinicopathological significance of caspase-3 and ki-67 expression in canine mammary gland tumours. Acta Veterinaria Hungarica, 64(1), 78-89.

Rudland, P. S., Platt-Higgins, A., Renshaw, C., West, C. R., Winstanley, J. H., Robertson, L., \& Barraclough, R. (2000). Prognostic significance of the metastasisinducing protein S100A4 (p9Ka) in human breast cancer. Cancer Research, 60(6), 1595-1603.

Sagan, D., Kocki, T., Patel, S., \& Kocki, J. (2015). Utility of kynurenic acid for non-invasive detection of metastatic spread to lymph nodes in non-small cell lung cancer. International Journal of Medicine, 12 (2), 146-153.

Sahabi, K., Selvarajah, G. T., Abdullah, R., Cheah, Y. K., \& Tan, G. C. (2018). Comparative aspects of microRNA expression in canine and human cancers. Journal of Veterinary Science, 19(2), 162171.

Salama, I., Malone, P. S., Mihaimeed, F., \& Jones, J. L. (2008). A review of the S100 proteins in cancer. European Journal of Surgical Oncology, 34
(4), 357-364.

Scheuner, D., Song, B., McEwen, E., Liu, C., Laybutt, R., Gillespie, P., ... \& Kaufman, R. J. (2001). Translational control is required for the unfolded protein response and in vivo glucose homeostasis. Molecular Cell, 7(6), 1165-1176.

Santos, A. A., Lopes, C. C., Ribeiro, J. R., Martins, L. R., Santos, J. C., Amorim, I. F., ... \& Matos, A. J. (2013). Identification of prognostic factors in canine mammary malignant tumours: a multivariable survival study. BMC Veterinary Research, 9(1), 1.

Scholzen, T., \& Gerdes, J. (2000). The Ki-67 protein: from the known and the unknown. Journal of Cellular Physiology, 182(3), 311-322.

Shi, Q. M., Luo, J., Wu, K., Yin, M., Gu, Y. R., \& Cheng, X. G. (2016). High level of $\alpha B$-crystallin contributes to the progression of osteosarcoma. Oncotarget, 7(8), 9007.

Shweiki, D., Itin, A., Soffer, D., \& Keshet, E. (1992). Vascular endothelial growth factor induced by hypoxia may mediate hypoxia-initiated angiogenesis. Nature, 359(6398), 843-845.

Sivadasan, P., Gupta, M. K., Sathe, G. J., Balakrishnan, L., Palit, P., Gowda, H., ... \& Sirdeshmukh, R. (2015). Human salivary proteome-a resource of potential biomarkers for oral cancer. Journal of Proteomics, 127, 89-95.

Sleeckx, N., De Rooster, H., Veldhuis Kroeze, E. J. B., Van Ginneken, C., \& Van Brantegem, L. (2011). Canine mammary tumours, an overview. Reproduction in Domestic Animals, 46(6), 1112-1131.

Sorenmo, K. (2003). Canine mammary gland tumors. Veterinary Clinics of North America Small Animal Practice, 33(3), 573-596.

Souza, J. V. (2002). Marker mucinous cancer associated. Revista Assoc Med Rio Grande Do Soul, 46, 70.

Szczubiał, M., Krawczyk, M., Bochniarz, M., Dąbrowski, R., Łopuszyński, W., \& Urban-Chmiel, R. (2018). Comparison of plasma interleukin- 6 and interleukin10 concentrations between female dogs with mammary gland tumours and healthy. Pakistan Veterinary Journal, 38(2), 194-198.

Takahashi, Y., Kitadai, Y., Bucana, C. D., Cleary, K. R., \& Ellis, L. M. (1995). Expression of vascular endothelial growth factor and its receptor, KDR, correlates with vascularity, metastasis, and proliferation of human colon cancer. Cancer Research, 55(18), 3964-3968.

Takeichi, M. (1990). Cadherins: a molecular family important in selective cell-cell adhesion. Annual Review of Biochemistry, 59(1), 237-252. 
Tavares, W. L., Lavalle, G. E., Figueiredo, M. S., Souza, A. G., Bertagnolli, A. C., Viana, F. A. B., ... \& Cassali, G. D. (2010). Evaluation of adverse effects in tamoxifen exposed healthy female dogs. Acta Veterinaria Scandinavica, 52(1), 67.

Tavasoly, A., Golshahi, H., Rezaie, A., \& Farhadi, M. (2013). Classification and grading of canine malignant mammary tumors. Veterinary Research Forum, 4(1), 25-30.

Vakkala, M., Pääkkö, P., \& Soini, Y. (1999). Expression of caspases 3, 6 and 8 is increased in parallel with apoptosis and histological aggressiveness of the breast lesion. British Journal of Cancer, 81(4), 592599.

Valko-Rokytovská, M., Očenáš, P., Salayová, A., \& Kostecká, Z. (2018). New developed UHPLC method for selected urine metabolites. Journal of Chromatography and Separation Techniques, 9 (404), 2.

Valko-Rokytovská $M$, Očenáš $P$, Salayová $A$, Titková $R$, Kostecká Z (2020). Specific urinary metabolites in canine mammary gland tumors. Journal of Veterinary Science, 21(2), e23.

Varallo, G. R., Gelaleti, G. B., Maschio[Signorini, L. B., Moschetta, M. G., Lopes, J. r., De Nardi, A. B., ... \& De Campos Zuccari, D. A. (2019). Prognostic phenotypic classification for canine mammary tumors. Oncology Letters, 18(6), 6545-6553.

Veldhoen, N., Watterson, J., Brash, M., \& Milner, J. (1999). Identification of tumour-associated and germ line p53 mutations in canine mammary cancer. British Journal of Cancer, 81(3), 409-415.

Von Kleist, S., Migule, I., \& Halla, B. (1995). Possible function of CEA as cell-contact inhibitory molecule. Anticancer Research, 15(5B), 1889.

Wiggins, T., Kumar, S., Markar, S. R., Antonowicz, S., \& Hanna, G. B. (2015). Tyrosine, phenylalanine, and tryptophan in gastroesophageal malignancy: a systematic review. Cancer Epidemiology, Biomarkers \& Prevention, 24(1), 32-38.

Yarden, Y., \& Sliwkowski, M. X. (2001). Untangling the ErbB signalling network. Nature Reviews Molecular Cell Biology, 2(2), 127-137.

Yildirim, F., Sonmez, K., Ozyogurtcu, H., Sennazlı, G., Gurel, A., Gunduz, M. C., \& Sontas, B. H. (2013). Evaluation of $\mathrm{Bcl}-2, \mathrm{Bcl}-\mathrm{XL}$ and Bax Expression and
Apoptotic Index in Canine Mammary Tumors. Kafkas Üniversitesi Veteriner Fakultesi Dergisi, 20(4), 513520.

Yoshikawa, Y., Morimatsu, M., Ochiai, K., IshiguraOonuma, T., Wada, S., Orino, K., \& Watanabe, K. (2015). Reduced canine BRCA2 expression levels in mammary gland tumors. BMC Veterinary Research, 11(1), 159.

Zajkowska, M., Głażewska, E. K., Będkowska, G. E., Chorąży, P., Szmitkowski, M., \& Ławicki, S. (2016). Diagnostic power of vascular endothelial growth factor and macrophage colony-stimulating factor in breast cancer patients based on ROC analysis. Mediators of Inflammation. 2016.

Zapata, J. M., Krajewska, M., Krajewski, S., Huang, R. P., Takayama, S., Wang, H. G., ... \& Reed, J. C. (1998). Expression of multiple apoptosis-regulatory genes in human breast cancer cell lines and primary tumors. Breast Cancer Research Treatment, 47(2), 129-140.

Zeng, J. C., Zhang, Z., Li, T. Y., Liang, Y. F., Wang, H. M., Bao, J. J., ... \& Xu, J. F. (2013). Assessing the role of IL -35 in colorectal cancer progression and prognosis. International Journal of Clinical and Experimental Pathology, 6(9), 1806.

Zha, C., Jiang, X. H., \& Peng, S. F. (2015). iTRAQ-based quantitative proteomic analysis on S100 calcium binding protein $\mathrm{A} 2$ in metastasis of laryngeal cancer. Public Library of Science One, 10(4), e0122322.

Zhang, S., Wang, Z., Liu, W., Lei, R., Shan, J., Li, L., \& Wang, X. (2017). Distinct prognostic values of S100 mRNA expression in breast cancer. Scientific Reports, 7(1), 1-11.

Zhang, Y., Sun, H., Wu, H., Tan, Q., \& Xiang, K. (2015). Interleukin 35 is an independent prognostic factor and a therapeutic target for nasopharyngeal carcinoma. Contemporary Oncology, 19(2), 120.

Zingg, H. H., \& Laporte, S. A. (2003). The oxytocin receptor. Trends Endocrinology Metabolism, 14(5), 222-227.

Zuccari, D. A., Santana, A. E., Cury, P. M., \& Cordeiro, J. A. (2004). Immunocytochemical study of Ki-67 as a prognostic marker in canine mammary neoplasia. Veterinary Clinical Pathology, 33(1), 2328. 